\title{
Osteogenic differentiation and inflammatory response of recombinant human bone morphogenetic protein-2 in human maxillary sinus membrane-derived cells
}

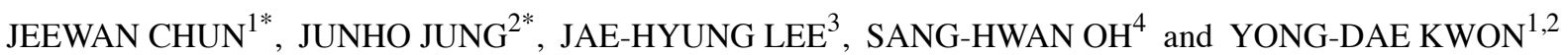 \\ ${ }^{1}$ Department of Dentistry, Graduate School; ${ }^{2}$ Department of Oral and Maxillofacial Surgery; \\ ${ }^{3}$ Department of Maxillofacial Regenerative Medicine, School of Dentistry, Kyung Hee University, Seoul 02447; \\ ${ }^{4}$ Department of Dental Hygiene, College of Medical Science, Konyang University, Daejeon 35365, Republic of Korea
}

Received December 26, 2019; Accepted June 2, 2020

DOI: $10.3892 /$ etm.2020.9208

\begin{abstract}
The aim of the present study was to investigate the osteogenic potential of human maxillary sinus membrane (hMSM)-derived cells, and the role of recombinant human bone morphogenetic protein-2 (rhBMP-2) in the inflammatory response of hMSM-derived cells and gingival fibroblasts following sinus floor elevation procedure (SFE). hMSM-derived cells from the samples were isolated, subcultured, and analyzed using immunohistochemical staining and flow cytometry. The hMSM-derived cells obtained from passage 6 were used for Alizarin Red staining and quantitative reverse transcription-quantitative PCR to observe its osteogenic activity and inflammatory reaction upon supplementation with rhBMP-2. The hMSM-derived cells were shown to be heterogeneous, as indicated by their positive expression of human mesenchymal stem cell markers (STRO-1, high mobility group AT-hook 2, CD44, CD105 and OCT-3/4), fibroblast cell marker (fibroblast-specific protein 1) and epithelial cell marker (epithelial cell adhesion molecule). Calcium nodules were found to be more notably evident in the rhBMP-2 group, following osteogenic differentiation. The gene expression of osteogenic markers was significantly upregulated in the cells supplemented with rhBMP-2. Supplementation with rhBMP-2 also enhanced the expression of inflammatory markers in hMSM-derived cells and gingival fibroblasts; however, $\mathrm{NF}-\kappa \mathrm{B}$ and TNF- $\alpha$ expression was not significantly increased
\end{abstract}

Correspondence to: Professor Yong-Dae Kwon, Department of Oral and Maxillofacial Surgery, School of Dentistry, Kyung Hee University, 26 Kyungheedae-ro, Dongdaemun-gu, Seoul 02447, Republic of Korea

E-mail: kwony@khu.ac.kr

*Contributed equally

Key words: maxillary sinus, recombinant human bone morphogenetic protein-2, mesenchymal stem cells, osteogenic potential, inflammation compared with the control in the hMSM-derived cells. hMSM contains mesenchymal stem cells (MSCs) capable of differentiating into osteogenic cells. The supplementation of rhBMP-2 enhanced osteogenic differentiation and induced an inflammatory response which was greater in gingival fibroblasts compared with hMSM-derived cells. In summary, the hMSM is a potential contributor to the osteogenic process following SFE, and the use of rhBMP-2 may increase the inflammatory response accordingly. The gingival tissue may be responsible for the increased inflammatory response by rhBMP-2 and postoperative complications.

\section{Introduction}

Dental implantation at the posterior maxilla can be challenging due to insufficient subantral bone volume that is primarily caused by alveolar ridge resorption and pneumatization of the maxillary sinus (1). To ensure sufficient bone volume, sinus floor elevation (SFE) is now widely utilized and has yielded clinically favorable results (1). Various bone substitutes including allograft, xenograft and alloplastic materials are used for SFE, and their use as a scaffold for osteoconduction and vascular ingrowth has been documented in numerous studies (2-5). Previous studies have shown that SFE without graft material can also provide new bone formation that would be sufficient to support a dental implant by lifting the human maxillary sinus membrane (hMSM) and maintaining its position (6-8). These findings confirm the importance of secluded spaces where blood clots can form and act as a scaffold to allow osteoconduction and vascular ingrowth $(9,10)$.

The residual maxillary bone, including the sinus floor and sinus walls, provides cellular components, such that bone and vessels can grow centripetally into grafted materials or into the secluded spaces from the residual bone following $\operatorname{SFE}(11,12)$. In addition, it is possible that the hMSM contains cells with osteogenic potential that may act as an additional source for new bone formation in SFE (13). Although the hMSM does not contain osteogenic cells in the tissue, several studies confirmed that the hMSM contains progenitor cells with a mesenchymal lineage that can potentially differentiate into an osteogenic lineage (14-19). 
Bone morphogenetic proteins (BMPs) are multi-functional growth factors and members of the transforming growth factor- $\beta$ (TGF- $\beta$ ) superfamily (20); of these, BMP-2 modulates osteoblastic differentiation through the BMP/Smad pathway (21-23). BMP-2 binds to the BMPreceptor and activates the cytoplasmic serine/threonine kinase of the BMP receptor (BMPR)-I. The activated BMPRs phosphorylate BMP-specific Smad1/5/8 in the cytoplasm. Smad1/5/8 binds Smad4, and the resultant complex is transported to the nucleus to promote the expression of a transcription factor with a homeodomain called Dlx5. This protein domain promotes the expression of runt-related transcription factor 2 (RUNX2) and Osterix, both of which are key transcription factors involved in osteoblast differentiation $(24,25)$. Therefore, recombinant human BMP (rhBMP-2) among other types of BMPs have been primarily utilized with a variety of bone graft materials to accelerate bone regeneration (26-33). The application of rhBMP-2 in SFE has been widely assessed in preclinical and clinical studies in which its osteoinductive and osteogenic capacities were confirmed $(34,35)$; however, with the increased use of rhBMP-2, its side effects became apparent, and these include inflammatory complications, ectopic bone formation, bone resorption and inflammatory swelling (36,37). Inflammatory swelling is the most common side effect following SFE with rhBMP-2 (38). It has been suggested that the cellular components in the hMSM and gingival tissue are involved in the inflammatory response following rhBMP-2 treatment $(36,37)$. However, the effect of rhBMP-2 on hMSM-derived cells has not been investigated.

The aim of the present study was to investigate the osteogenic differentiation potential of hMSM-derived cells and the effect of rhBMP-2 on these cells with the aim of identifying the cause of the inflammatory response.

\section{Materials and methods}

Subjects. hMSM samples were collected from three individuals (1 male and 2 females, 17-33 years of age) who underwent Le Fort I osteotomy as the orthognathic surgery between April and October 2016, with a discarded hMSM available. Informed consent was obtained, and all samples were collected in accordance with relevant guidelines under and ethically approved by the Ethics Committee at the Kyung Hee University Dental Hospital (approval no. KHD IRB 1509-1). Patients who neither had experienced nor were diagnosed with sinus pathology, maxillary neoplasm, metabolic diseases, genetic disease, nor had a history of previous sinus surgery were selected. After the collection, the samples were suspended in Dulbecco's PBS (DPBS; Corning, Inc.) containing 1\% penicillin-streptomycin (PS; Corning, Inc.). Samples that were $\sim 1 \mathrm{x} 1 \mathrm{~cm}$ in size were used for cell culture.

Histological analysis. Samples were fixed in $3.7 \%$ paraformaldehyde pH 7.4 (cat. no. P2031; Biosesang, Inc.) overnight at $4^{\circ} \mathrm{C}$, dehydrated using a series of ethanol solutions of increasing concentrations $(50 \%$ ethanol, $70 \%$ ethanol and $100 \%$ ethanol), and embedded in paraffin. Tissue sections $4 \mu \mathrm{m}$ thick were incubated in Mayer's hematoxylin solution (Lillie's Modification) for 5 min and eosin Y solution (modified alcoholic) for $3 \mathrm{~min}$ at $25^{\circ} \mathrm{C}$ using hematoxylin and eosin (H\&E) staining kit (cat. no. ab245880; Abcam), and mouse and rabbit specific HRP/DAB IHC detection kit (cat. no. ab236466; Abcam, the avidin-biotin-peroxidase complex (ABC) method according to the manufacturer's protocol. Cell markers, including STRO-1 (cat. no. MAB1038-SP; 1:100; R\&D Systems, Inc.), high mobility group AT-hook 2 (HMGA-2; cat. no. 8179S; 1:400; Cell Signaling Technology, Inc.), epithelial cell adhesion molecule (EpCAM; cat. no. 2929S; 1:500; Cell Signaling Technology, Inc.) and fibroblast-specific protein-1 (FSP-1; 13018S; 1:400; Cell Signaling Technology, Inc.) were used as the primary antibodies.

Isolation and culture of hMSM cells. For the isolation of hMSM cells, the samples were rinsed with DPBS to remove erythrocytes. Tissues were cut into $1-2 \mathrm{~mm}$ pieces and digested with $1 \%$ type I collagenase (Gibco; Thermo Fisher Scientific, Inc.) at $37^{\circ} \mathrm{C}$ for $3 \mathrm{~h}$ in $60 \mathrm{~mm}$ petri dishes. Enzyme activity was neutralized with the addition of DMEM containing $10 \%$ FBS (Corning, Inc.) and $1 \%$ PS, and the samples were centrifuged at $196 \times \mathrm{g}$ at $25^{\circ} \mathrm{C}$ for $3 \mathrm{~min}$. The pellet was resuspended and transferred into a plate containing the culture medium, and the cells were incubated overnight at $37^{\circ} \mathrm{C}$ with $5 \% \mathrm{CO}_{2}$ to allow adherence. Subsequently, the cell cultures were washed with DPBS to remove residual non-adherent tissues and erythrocytes. The morphology of hMSM cells was observed daily using an inverted phase-contrast microscope and the culture medium was changed every two days. When the monolayer of adherent cells reached $70-80 \%$ confluence, the cells were trypsinized (TrypLE ${ }^{\mathrm{TM}}$ Express; Gibco; Thermo Fisher Scientific, Inc.), resuspended in growth medium and subcultured.

Immunohistochemical (IHC) analysis. hMSM-derived cells recovered from passage 6 (P6) were subcultured in 12-well culture plates at a density of $1 \times 10^{5}$ cells/well. Cells were fixed in $3.7 \%$ paraformaldehyde for $20-30 \mathrm{~min}$ at $25^{\circ} \mathrm{C}$ and blocked with antibody diluent (GBI Labs, Inc.) overnight at $4^{\circ} \mathrm{C}$. Subsequently, cells were incubated with anti-STRO-1 (cat. no. sc-47733; 1:100; Santa Cruz Biotechnology, Inc.), HMGA-2 (1:400; Cell Signaling Technology, Inc.), CD44 (cat. no. sc-7297; 1:200; Santa Cruz Biotechnology, Inc.), CD105 (cat. no. ab169545; 1:400; Abcam), EpCAM (1:400), FSP-1 (1:400) or CD34 (cat. no. sc-7324; 1:200; Santa Cruz Biotechnology, Inc.) overnight at $4^{\circ} \mathrm{C}$. After incubation, the wells were washed five times with DPBS. Each sample was incubated with secondary antibodies (cat. no. A11001; 1:1,000; Invitrogen; Thermo Fisher Scientific, Inc.; cat. no. A11034; 1:1,000; Invitrogen; Thermo Fisher Scientific, Inc.) for $1 \mathrm{~h}$ at $25^{\circ} \mathrm{C}$. The cells were counterstained with DAPI. Images were analyzed under x200 and 400 magnification fields using light and fluorescence microscopy (IX71-F32PH; Olympus Corporation).

Flow cytometry analysis. hMSM-derived cells obtained at passage (P)2, P4, P6 and P8 were analyzed by flow cytometry to assess the expression of various markers. Cultures with a density of $1 \times 10^{6}$ cells $/ \mathrm{ml}$ were fixed in $3.7 \%$ paraformaldehyde for $20 \mathrm{~min}$ at $25^{\circ} \mathrm{C}$ and then blocked with antibody diluent overnight at $4^{\circ} \mathrm{C}$. The cells were then labeled with monoclonal antibodies against STRO-1, EpCAM, HMGA2 and FSP-1 
overnight at $4^{\circ} \mathrm{C}$ and washed five times with DPBS. The secondary antibodies coupled with FITC were added, and the cells were incubated for $1 \mathrm{~h}$ at $25^{\circ} \mathrm{C}$ in the dark. After labeling, cells were washed and resuspended in DPBS, and analyzed using a LSRFortessa ${ }^{\mathrm{TM}}$ X-20 flow cytometer (BD Biosciences).

Alizarin Red staining. hMSM-derived cells from P6 were cultured in 6-well plates $\left(3 \times 10^{5}\right.$ cells/well) with non-osteogenic medium (DMEM containing 10\% FBS and 1\% PS), osteogenic medium [DMEM containing 10\% FBS, $1 \%$ PS, $5 \mu \mathrm{M} \beta$-glycerophosphate (Sigma-Aldrich; Merck KGaA), $0.1 \mathrm{mM}$ ascorbic acid (Sigma-Aldrich; Merck KGaA) and $0.1 \mu \mathrm{M}$ dexamethasone (Sigma-Aldrich; Merck KGaA)] or osteogenic medium supplemented with rhBMP-2 $(10 \mathrm{ng} / \mathrm{ml}$; PeproTech Inc.). After 0,7 and 14 days of culture, the cells were fixed with $3.7 \%$ paraformaldehyde (cat. no. P2031; Biosesang, Inc.) for $30 \mathrm{~min}$ at $25^{\circ} \mathrm{C}$ and rinsed with DPBS. The cells were subsequently stained with $2 \%$ Alizarin Red solution (cat. no. 6B7131; Sigma-Aldrich; Merck KGaA) for $20 \mathrm{~min}$ at $25^{\circ} \mathrm{C}$, and rinsed five times with DPBS to remove non-specific stained cells.

Reverse transcription-quantitative $(R T-q) P C R$ for osteogenic activity and inflammatory reaction. To investigate the expression of genes associated with osteogenic differentiation, hMSM-derived cells from P6 were cultured $\left(3 \times 10^{5}\right.$ cells/well) in 6-well plates for 14 days. The cells were cultured in the osteogenic medium with or without $10 \mathrm{ng} / \mathrm{ml} \mathrm{rhBMP}-2$. The markers used for RT-qPCR are presented in Table I, including the sequences of the primers used and the expected amplicon size. To investigate the expression of genes relevant to the inflammatory response caused by rhBMP-2, MSM-derived cells and gingival fibroblast cells (P4) were cultured $\left(5 \times 10^{5}\right.$ cells/well) for $0,24,48$ and $72 \mathrm{~h}$. The control group was cultured in DMEM containing $10 \%$ FBS and $1 \%$ PS. The experimental groups were cultured in DMEM containing $10 \%$ FBS and $1 \%$ PS with $10 \mathrm{ng} / \mathrm{ml}$ rhBMP-2. Total RNA was isolated from control and experimental cultures at defined time intervals using a Ribospin ${ }^{\mathrm{TM}}$ RNA isolation kit (GeneAll, Biotechnology, Co. Ltd.) according to the manufacturer's protocol. RNA was collected in RNAse free water, and its total quantity and quality were measured spectrophotometrically (Nanodrop 2000/2000c spectrophotometer; Thermo Fisher Scientific, Inc.). First strand cDNA was synthesized from total RNA using AccuPower ${ }^{\circledR}$ CycleScript RT PreMIX(dT20) (Bioneer Corporation) according to the manufacturer's protocol. After cDNA synthesis, qPCR was performed using $1 \mu \mathrm{g}$ cDNA mixed with $10 \mu \mathrm{l}$ SYBR-Green using TOPreal ${ }^{\mathrm{TM}}$ qPCR 2x PreMIX (Enzynomics, Co., Ltd.), with $5 \mu \mathrm{M}$ each of the forward and reverse primers. The PCR thermocycling conditions were: Initial denaturation at $95^{\circ} \mathrm{C}$ for $15 \mathrm{~min}$; followed by 40 cycles of denaturation at $95^{\circ} \mathrm{C}$ for $15 \mathrm{sec}$, annealing at primer melting temperature (Tm) for $10 \mathrm{sec}$ and extension at $72^{\circ} \mathrm{C}$ for $30 \mathrm{sec}$. Expression levels of the target genes were quantified after normalization to the levels of $\beta$-actin using the $2^{-\Delta \Delta \mathrm{Cq}}$ method (39).

Statistical analysis. Results are expressed as individual data or as the mean \pm the standard error of the mean of at least three repeats. Statistical analysis was performed using a Wilcoxon
Table I. Sequences of the primers used and the expected amplicon size.

\begin{tabular}{|c|c|c|}
\hline Gene & Sequence, 5'-3' & Size, bp \\
\hline$\beta$-actin & & 110 \\
\hline Forward & GTCAGGCAGCTCGTGCTCT & \\
\hline Reverse & TCGTGCGTGACATTAAGGAG & \\
\hline RUNX2 & & 189 \\
\hline Forward & GTAGCTACTTGGGGAGGATT & \\
\hline Reverse & AGATGGGACTGTGGTTACTG & \\
\hline ALP & & 102 \\
\hline Forward & TCCATGTTGAGATGAGCTG & \\
\hline Reverse & ACACACAGTGAACCGCAACT & \\
\hline Osteocalcin & & 143 \\
\hline Forward & CGCCTGGGTCTCTTCACTAC & \\
\hline Reverse & CTCACACTCCTCGCССТАTT & \\
\hline Type I collagen & & 105 \\
\hline Forward & ATGACAATCTGCTCCCAAC & \\
\hline Reverse & CAATGCTGTTCTTGCAGTGG & \\
\hline $\mathrm{NF}-\kappa \mathrm{B}$ & & 158 \\
\hline Forward & AGATGTGGTGGAGGATTTGC & \\
\hline Reverse & TGGGGTGGTCAAGAAGTAGTG & \\
\hline TNF- $\alpha$ & & 116 \\
\hline Forward & CAAGGATGTCATTGGTGACG & \\
\hline Reverse & CCTTGGTCTGCTTCTTCTCC & \\
\hline IL-1 $\beta$ & & 133 \\
\hline Forward & TCCAGGGACAGGATATGGAG & \\
\hline Reverse & TCTTTCAACACGCAGGACAG & \\
\hline IL-6 & & 179 \\
\hline Forward & AGGCACTGGCAGAAAACAAC & \\
\hline Reverse & AGCTCTGGCTTGTTCCTCAC & \\
\hline
\end{tabular}

RUNX2, runt-related transcription factor 2; ALP, alkaline phosphatase; NF- $\kappa \mathrm{B}$, nuclear factor- $\kappa \mathrm{B}$; TNF- $\alpha$, tumor-necrosis factor- $\alpha$; IL, interleukin.

signed ranks test and a Mann-Whitney U test in SPSS version 15.0 (SPSS, Inc.). $\mathrm{P}<0.05$ was considered to indicate a statistically significant difference.

\section{Results}

Histological findings. H\&E staining allowed visualization of the epithelial lining, lamina propria and periosteal-like lining (Fig. 1A-C). The hMSM sections were also stained using the ABC method, which revealed a number of cells positive for the mesenchymal stem/stromal cell (MSC) marker (STRO-1), fibroblast marker (FSP-1) and epithelial cell marker (EpCAM) (Fig. 1D-F).

Morphological and IHC findings. Adherent hMSM-derived cells were heterogeneous, consisting of epithelial-like cells with a polygonal shape and fibroblast-like cells with a bipolar elongated shape. As the number of cell passages increased, 

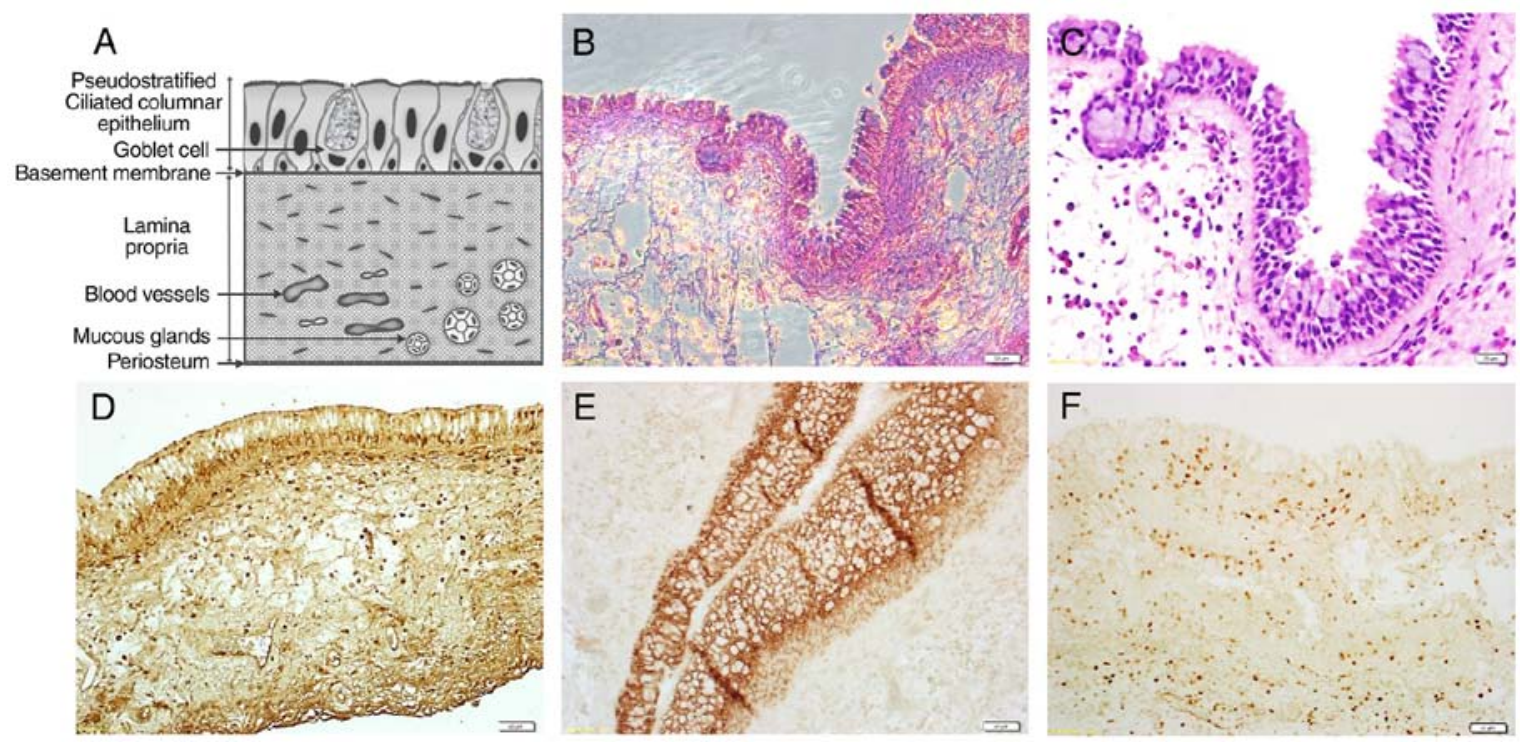

Figure 1. Tissue section of the hMSM. A general view of a stained hMSM section, showing the epithelial lining, vascularized lamina propria and deepest periosteal-like lining. (A) An illustration of an hMSM section. (B and C) Hematoxylin \& eosin staining. Scale bar, 50 and $20 \mu \mathrm{m}$, respectively. Avidin-biotin-peroxidase complex staining for (D) STRO-1, (E) EpCAM, and (F) FSP-1, respectively. Scale bar, $50 \mu$ m. hMSM, human maxillary sinus membrane; EpCAM, epithelial cell adhesion molecule.

the number of fibroblast-like cells also increased. The hMSM-derived cells expressed MSC markers such as STRO-1, HMGA2, CD44 and CD105 but they did not express the hematopoietic marker CD34. The epithelial cell marker EpCAM and fibroblast marker FSP-1 were also expressed (Fig. 2).

Flow cytometry. The hMSM-derived cells expressed STRO-1, HMGA2, EpCAM and FSP-1 markers in all examined passages (P2, P4, P6 and P8). The signals for these markers increased between P2 to P6, but decreased at P8. Cells positive for the MSC markers (STRO-1 and HMGA2) peaked at P6 (Fig. 3).

Osteogenic activity. Calcium nodules stained with Alizarin Red $\mathrm{S}$ became more evident as the culture period increased, and were most numerous in the rhBMP-2 group (Fig. 4A and B). RT-qPCR was performed to analyze the gene expression of the osteogenic markers including alkaline phosphatase (ALP), RUNX2, type 1 collagen and osteocalcin following osteogenic differentiation. The expression of the osteogenic genes was significantly higher in the rhBMP-2 groups compared with the control group (Fig. 5). Expression of all these markers were upregulated after 7 and 14 days of culture. Apart from ALP, the expression of the markers in the rhBMP-2 group was significantly higher after 14 days compared with after 7 days. ALP expression in the rhBMP-2 group was higher (up to 24-fold) upon measurement after 7 days of culture compared with day 0 , and subsequently significantly decreased in both control and rhBMP-2 groups.

Inflammatory reaction to rhBMP-2. As shown in Fig. 6, the gene expression of nuclear factor- $\mathrm{kB}(\mathrm{NF}-\mathrm{\kappa B})$ in the hMSM-derived cell and gingival fibroblast groups gradually increased over time, with an 8.2-fold and 15.9-fold increase in expression after $72 \mathrm{~h}$ of incubation, respectively. However, the gene expression of NF- $\mathrm{KB}$ in the hMSM-derived cells did not differ significantly compared with the control group. Tumor necrosis factor (TNF)- $\alpha$ in the hMSM-derived cell group treated with rhBMP-2 was

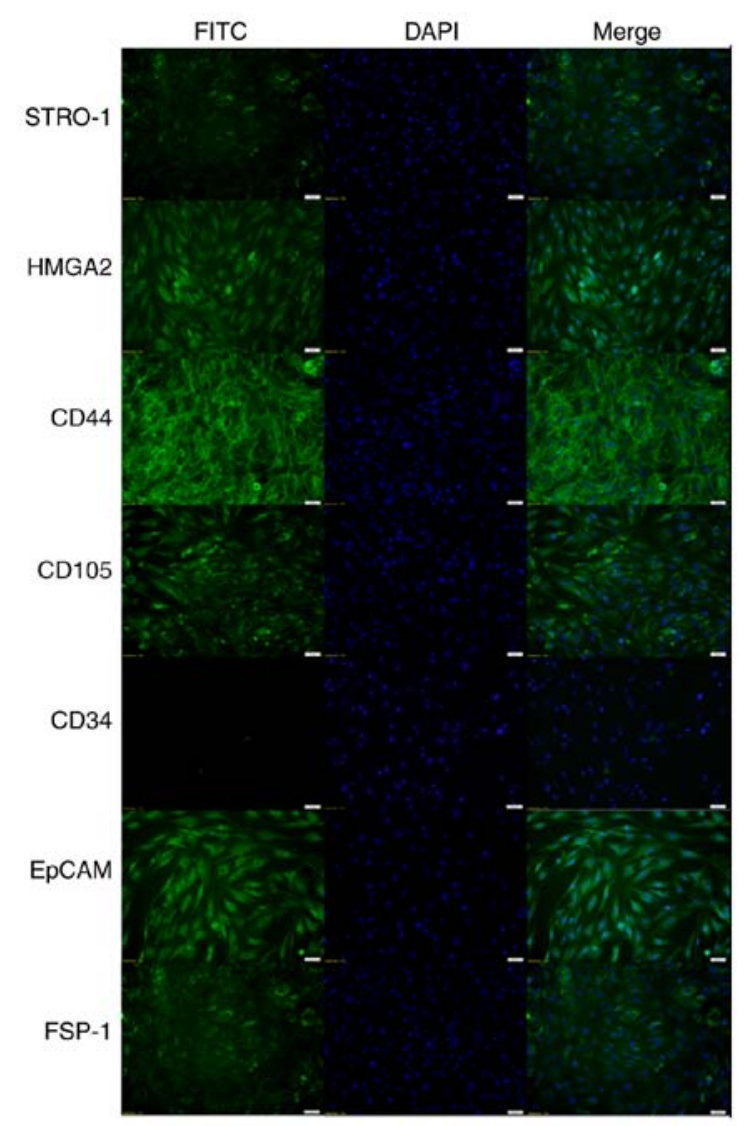

Figure 2. Immunohistochemical images of cell markers in human maxillary sinus membrane-derived cells. The nuclei were stained with DAPI (blue). Scale bar, $50 \mu \mathrm{m}$.

significantly lower compared with the control group; however, in the gingival fibroblast group, it was significantly higher compared with the control group. Interleukin (IL)-1 $1 \beta$ expression peaked at $48 \mathrm{~h}$ with a 2.9 -fold increase in expression compared 

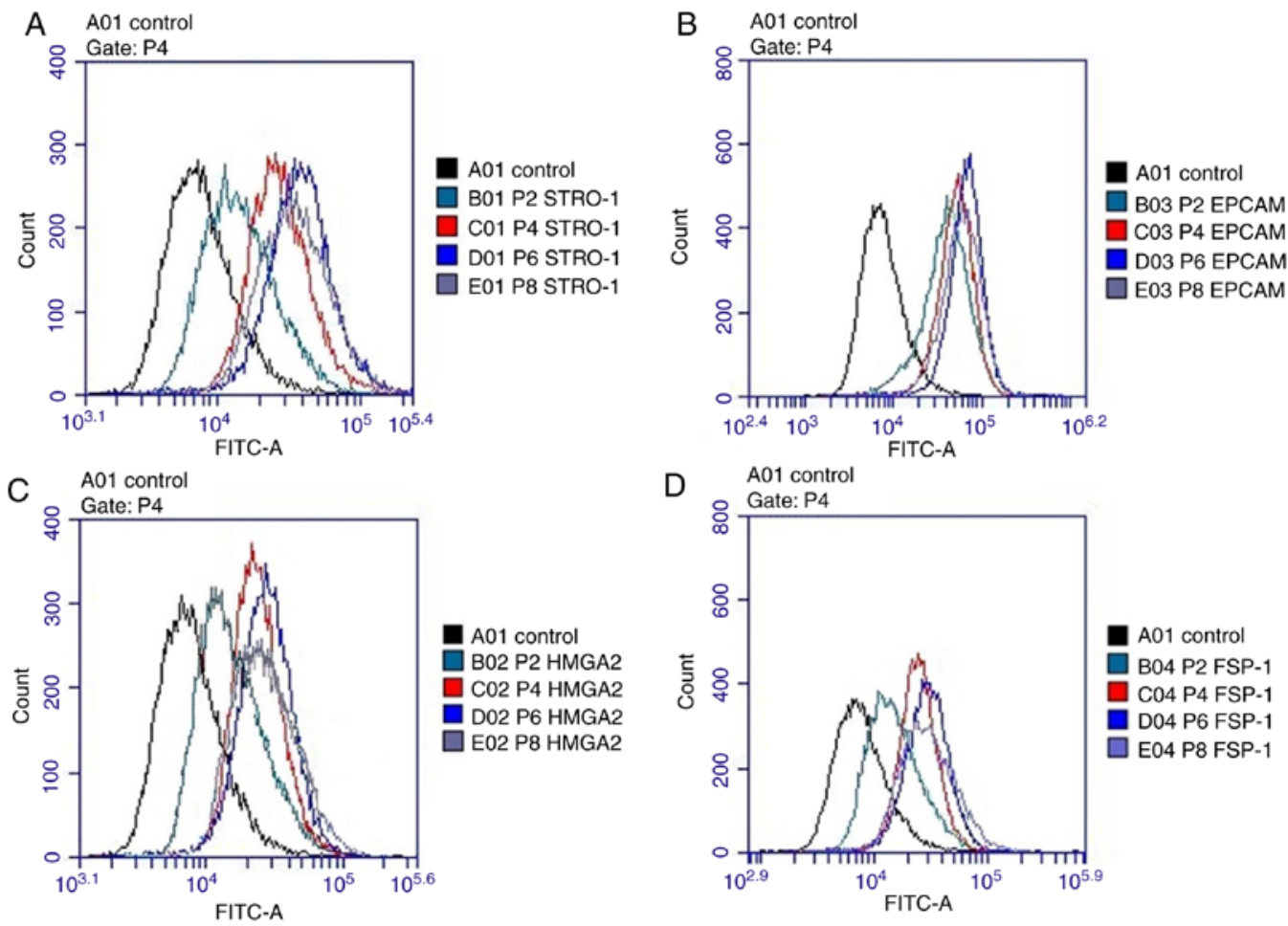

Figure 3. Flow cytometry analysis of hMSM-derived cells at P2, P4, P6 and P8. (A) STRO-1, (B) HMGA-2, (C) EpCAM and (D) FSP-1. The markers were used to characterize hMSM-derived cells and to compare the expression levels according to the number of cell passages. hMSM, human maxillary sinus membrane; P, passage number; HMGA-2, high mobility group AT-hook 2; FSP-1, fibroblast-specific protein 1; FITC, fluorescein isothiocyanate.

A
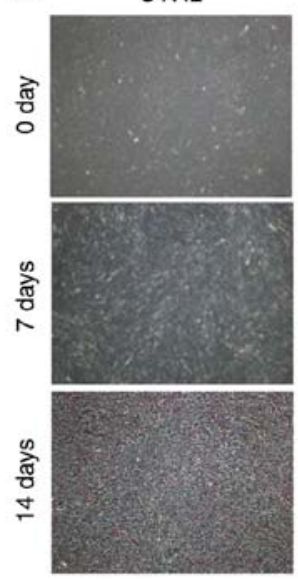

os

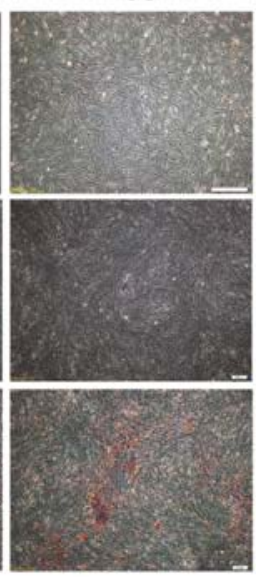

BMP-2

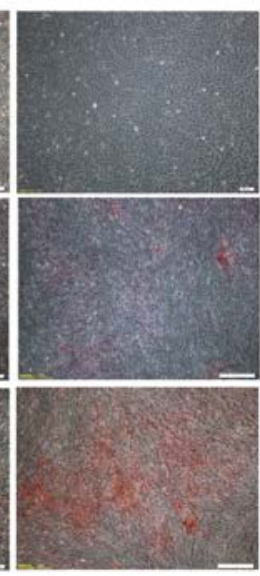

B

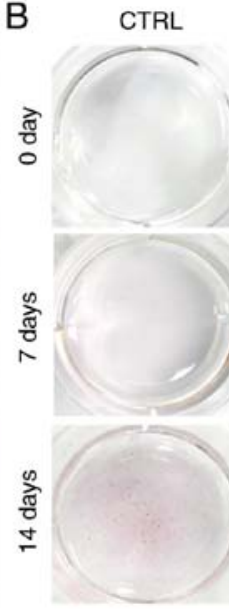

os

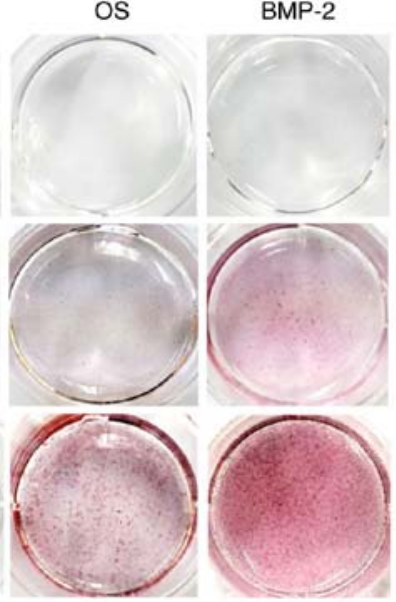

Figure 4. Alizarin Red staining for hMSM-derived cells. (A and B) Cells were cultured in CTRL, OS medium or OS medium supplemented with recombinant human BMP-2. The control and experimental groups were evaluated for calcium production at 0,7 , and 14 days. hMSM, human maxillary sinus membrane; CTRL, normal medium; OS, osteogenic; BMP-2, bone morphogenetic protein-2.

with the control in the hMSM-derived cells, and at $24 \mathrm{~h}$ with a 3.8-fold increase in gingival fibroblasts. The expression of IL-6 gene expression peaked at $72 \mathrm{~h}$, with a 3 -fold increase in the hMSM-derived cells, and an 18-fold increase in gingival fibroblast cells. The expression of IL-1 $\beta$ and IL- 6 in both groups was significantly higher compared with the control group.

\section{Discussion}

SFE has become a standard procedure to increase subantral bone volume at the atrophic posterior maxilla (39-41).
Autogenous bone, allograft, xenograft and alloplastic materials have been used as bone graft materials (2). Since xenograft and alloplastic materials are only osteoconductive, osteogenic and angiogenic cells and growth factors from the residual maxillary bone serve a crucial role in osteogenesis (42). In addition, the presence of human (h)MSCs is also an important factor for SFE, as hMSCs can differentiate into osteogenic cells (43). Therefore, if the hMSM contains hMSCs, osteogenesis is expected to occur following SFE, which is far from the sinus floor and walls. BMP-2 modulates osteoblastic differentiation through the BMP/Smad pathway by binding 

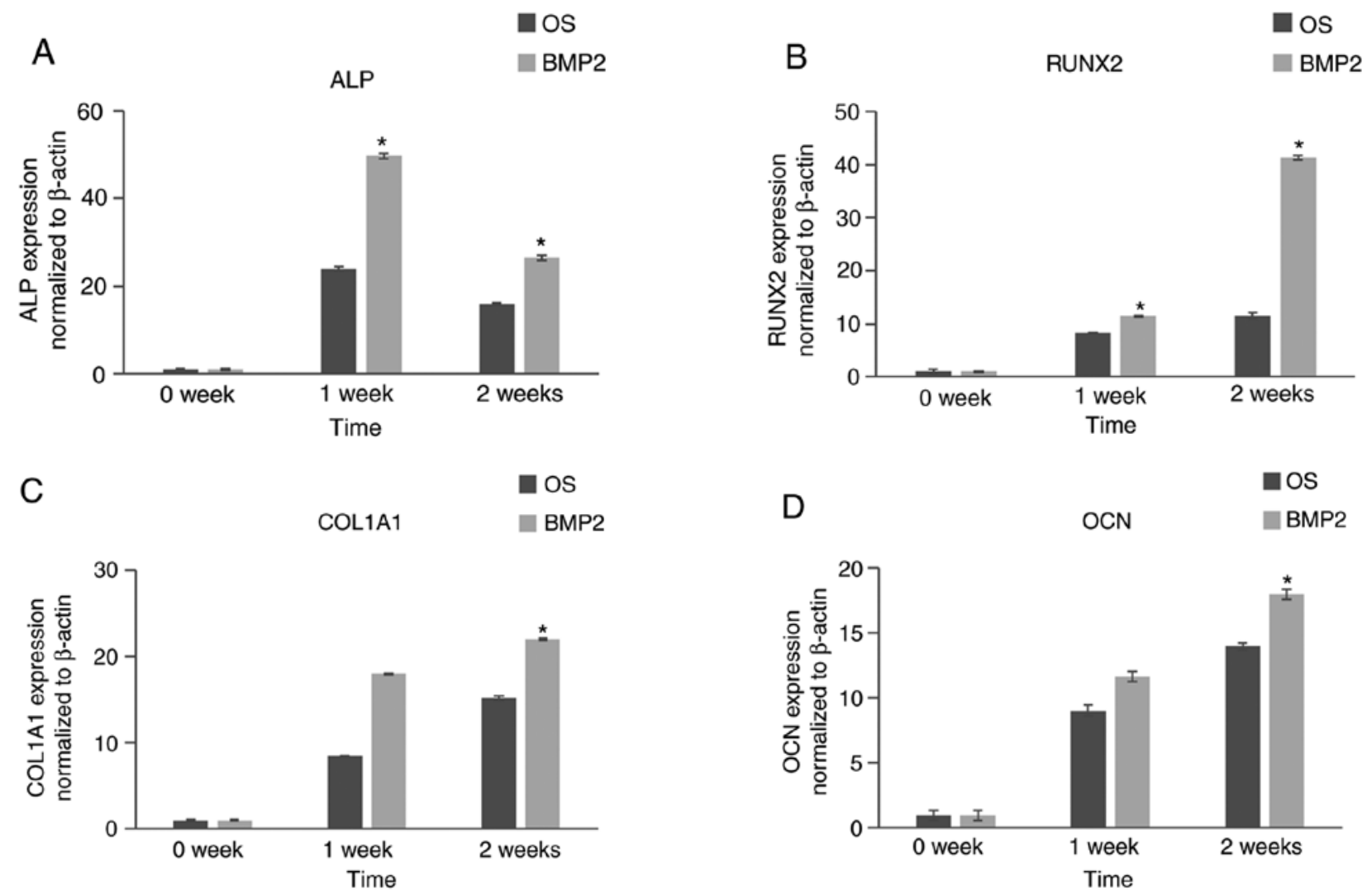

Figure 5. Reverse transcription-quantitative-PCR analysis for osteogenic markers. The experimental groups were divided into two groups: Cells cultured in OS medium or OS medium supplemented with recombinant human BMP-2. (A) ALP, (B) RUNX2, (C) COL1A1 and (D) OCN. Data were normalized to $\beta$-actin expression. "P $<0.05$. Error bars indicate the standard error of the mean. OS, osteogenic; ALP, alkaline phosphatase; RUNX2, runt-related transcription factor 2; COL1A1, Type I collagen; OCN, osteocalcin.

to the BMP receptor (21-24). Accordingly, the present study was designed to verify if the hMSM contains a type of MSCs that exhibits the potential to differentiate into osteogenic cells, and if BMP-2 could enhance the osteogenic differentiation of the hMSM derived cells. In addition, the role of BMP-2 in eliciting an inflammatory response was investigated according to cellular composition and tissue type, as it is possible that the use of BMP-2 may increase postoperative complications following SFE (44).

The isolated hMSM-derived cells showed characteristics of epithelial-like cells and fibroblast-like cells morphologically, indicating that the cells were heterogeneous and may contain hMSCs (43-45). The presence of hMSCs was confirmed by STRO1, CD44, CD105 and HMGA2-positive cells (46). As STRO1-positive progenitors are considered to be derived from a perivascular niche, the MSCs could have arisen from developing blood vessels that are abundant in the hMSM tissue $(15,47,48)$. In addition, the presence of fibroblasts and epithelial cells were also confirmed by the presence of the fibroblast marker FSP-1 and the epithelial marker EpCAM (49,50). Interestingly, the number of cells exhibiting the morphological characteristics of mesenchymal progenitor cells and STRO1-positive cells increased with the increasing number of passages.

The hMSM-derived cells contained a cell population capable of differentiating into osteogenic cells. Calcified nodules were observed after 14 days of incubation in the osteogenic medium, and mineralization was enhanced with
rhBMP-2 supplementation. The gene expression of osteogenic markers including ALP, RUNX2, Type I collagen and osteocalcin, were also significantly upregulated in the presence of rhBMP-2 compared with those in the control group. These results suggest that the use of rhBMP-2 in SFE may induce and facilitate osteogenesis initiated by the hMSM-derived MSCs.

Several studies have suggested that the hMSM contains a population of multipotent stem cells that may contribute to osteogenesis. A study by Graziano et al (13) in which mesenchymal progenitors in the hMSM were isolated and characterized, showed that they possessed the intrinsic capacity to regenerate maxillary bone volume. Another study also reported that the hMSCs isolated from the hMSM were capable of generating bone-like tissue (15), in agreement with the results of the present study.

Currently, rhBMP-2 is widely used for bone regeneration as an osteoinductive adjuvant; however, concerns were raised, as postoperative complications associated with rhBMP-2 have been reported $(36-38,51,52)$. In 2008, the United States Food and Drug Administration issued a warning regarding the use of rhBMP-2, due to the risk of cervical spine swelling and death $(36,37)$, and there is a study describing local reactions, infections, wound complications and graft failures as common adverse events of BMP-2 use (38). Local reactions, such as edema, erythema and pain were the most frequently reported events, and this suggests that inflammatory reactions may increase with the use of rhBMP-2. According to the 


\section{I. hMSM-derived cells}

A $\square$ CTRL

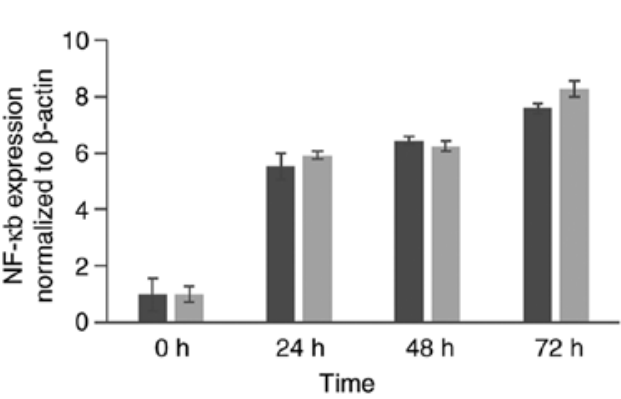

C

IL- $1 \beta$
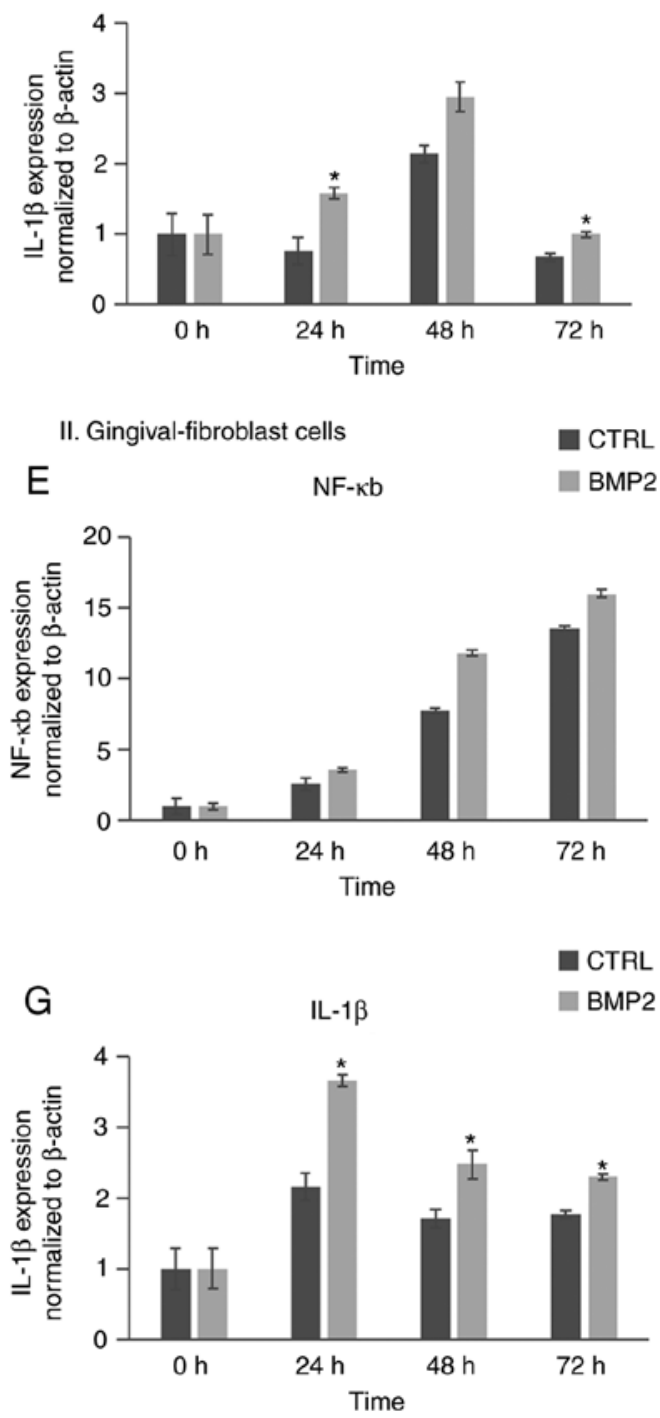

$\begin{array}{lll} & & \text { CTRL } \\ \text { B } & \text { TNF- } \alpha & \text { BMP2 }\end{array}$
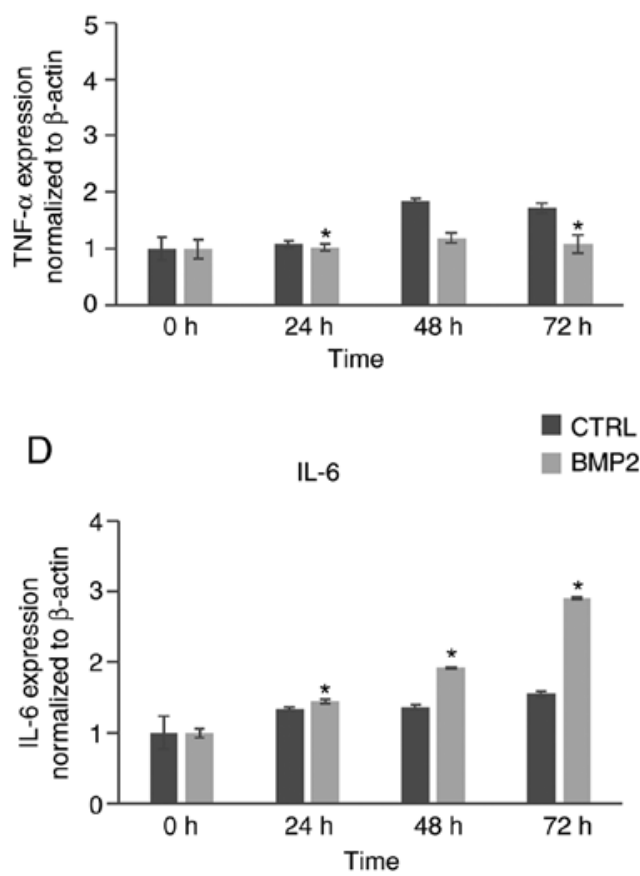

$\mathrm{F}-\quad \square \mathrm{CTRL}$
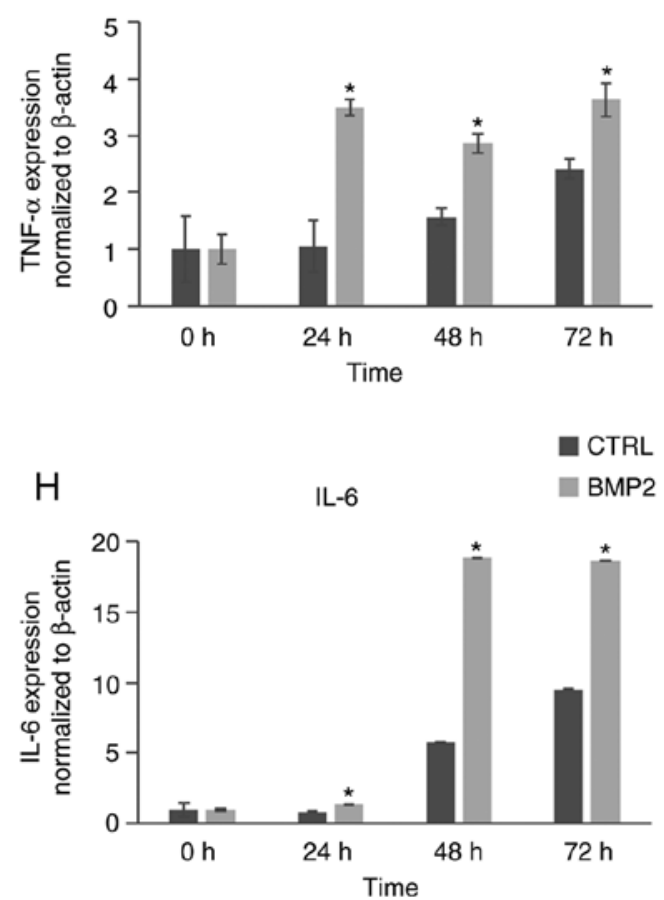

Figure 6. Reverse transcription-quantitative PCR analysis for the expression of inflammatory markers after supplementation with recombinant human BMP-2. The mRNA expression levels of NF- $\kappa$ B, TNF- $\alpha$, IL-1 $\beta$ and IL-6 were analyzed in (A-D) hMSM-derived cells and (E-H) gingival fibroblasts. Data were normalized to $\beta$-actin expression. ${ }^{*} \mathrm{P}<0.05$. Error bars indicate the standard error of the mean. BMP-2, bone morphogenetic protein-2; NF- $\kappa \mathrm{B}$, nuclear factor- $\kappa \mathrm{B}$; TNF- $\alpha$, tumor necrosis factor- $\alpha$; IL, interleukin; hMSM, human maxillary sinus membrane; CTRL, control.

side effects profile of BMP-2 reviewed by Nguyen et al (53), both in vitro and in vivo preclinical studies show that BMP-2 induces inflammation, as evidenced by increased levels of the inflammatory cytokines IL-1 $\beta$, IL-6, IL-10, IL-17, IL-18 and TNF- $\alpha(37,53,54)$.
In the present study, it was demonstrated that the mRNA expression levels of IL-1 $\beta$ and IL- 6 were significantly upregulated by rhBMP-2 in both groups. However, expression of TNF- $\alpha$, which regulates immune cells and induces inflammation, was significantly downregulated, and NF- $\mathrm{B}$ 
expression was not significantly different compared with the control in the hMSM-derived cells. On the contrary, the expression of these inflammatory markers were upregulated in the gingival fibroblast group. This result suggests that the hMSCs may serve a role in the decreased inflammatory response.

In agreement with this result, several studies have shown that MSCs modulate allogeneic immune cell responses, and that MSCs serve as guardians against excessive inflammatory responses (55-59). Aggarwal and Pittenger (55) demonstrated that hMSCs interact with a variety of immune cells to inhibit or limit the inflammatory response, and promote anti-inflammatory pathways; however, it is difficult to conclude if hMSCs serve a role in reducing inflammation, as the hMSM consists of various cell types and their inflammatory response is not balanced with the result.

Further studies are required to identify the mechanism and the role of hMSCs in the rhBMP-2 induced inflammatory response. The expression of the markers and BMP-2 receptor are required to verify these results, and various concentrations of rhBMP-2 should be examined, as rhBMP-2 initiates a dose-dependent inflammatory response (60). However, the present study showed that hMSM contributes to the osteogenic process through hMSCs, and that the use of rhBMP-2 in SFE increases the inflammatory response resulting in more acute postoperative complications than without the use of rhBMP-2 in conventional SFE. In addition, the severity of the inflammatory response may differ by region depending on the cellular composition of the tissue affected.

In conclusion, the present study confirmed that hMSM contains hMSCs that are capable of differentiating into osteogenic cells. Supplementation of rhBMP-2 enhances osteogenic differentiation. In addition, rhBMP-2 induced an inflammatory response, and the response was smaller in the hMSM-derived cells and larger in the gingival fibroblasts. The use of rhBMP-2 in SFE may increase the inflammatory response and the gingival tissue may be responsible for the increased response and postoperative complications. Extra precautions are required for the clinical use of rhBMP-2.

\section{Acknowledgements}

Not applicable.

\section{Funding}

This study was supported by a grant from the Korea Health Technology R\&D project through the Korea Health Industry Development Institute, funded by the Ministry of Health \& Welfare, Republic of Korea (grant no. HI14C0175).

\section{Availability of data and materials}

The datasets used and/or analyzed during the present study are available from the corresponding author on reasonable request.

\section{Authors' contributions}

JC and JJ wrote the manuscript. JC performed the experiments. $\mathrm{JJ}$ analyzed the data and revised the manuscript. J-HL and S-HO interpreted the results. Y-DK conceived and designed the study.

\section{Ethics approval and consent to participate}

Written informed consent was obtained from all participants, and all samples were collected in accordance with relevant guidelines and approved by the Ethics Committee at the Kyung Hee University Dental Hospital (approval no. KHD IRB 1509-1).

\section{Patient consent for publication}

Not applicable.

\section{Competing interests}

The authors declare that they have no competing interests.

\section{References}

1. Raghoebar GM, Onclin P, Boven GC, Vissink A and Meijer HJA: Long-term effectiveness of maxillary sinus floor augmentation: A systematic review and meta-analysis. J Clin Periodontol 46 (Suppl 21): S307-S318, 2019.

2. Stumbras A, Krukis MM, Januzis G and Juodzbalys G: Regenerative bone potential after sinus floor elevation using various bone graft materials: A systematic review. Quintessence Int 50: 548-558, 2019.

3. Helder MN, van Esterik FAS, Kwehandjaja MD, Ten Bruggenkate CM, Klein-Nulend J and Schulten E: Evaluation of a new biphasic calcium phosphate for maxillary sinus floor elevation: Micro-CT and histomorphometrical analyses. Clin Oral Implants Res 29: 488-498, 2018.

4. Farré-Guasch E, Prins HJ, Overman JR, Ten Bruggenkate CM, Schulten EA, Helder MN and Klein-Nulend J: Human maxillary sinus floor elevation as a model for bone regeneration enabling the application of one-step surgical procedures. Tissue Eng Part B Rev 19: 69-82, 2013.

5. Solar P, Geyerhofer U, Traxler H, Windisch A, Ulm C and Watzek G: Blood supply to the maxillary sinus relevant to sinus floor elevation procedures. Clin Oral Implants Res 10: 34-44, 1999.

6. Riben $\mathrm{C}$ and Thor A: Follow-up of the sinus membrane elevation technique for maxillary sinus implants without the use of graft material. Clin Implant Dent Relat Res 18: 895-905, 2016.

7. Sohn DS, Moon JW, Lee WH, Kim SS, Kim CW, Kim KT and Moon YS: Comparison of new bone formation in the maxillary sinus with and without bone grafts: Immunochemical rabbit study. Int J Oral Maxillofac Implants 26: 1033-1042, 2011.

8. Parra M, Olate S and Cantin M: Clinical and biological analysis in graftless maxillary sinus lift. J Korean Assoc Oral Maxillofac Surg 43: 214-220, 2017.

9. Stefanski S, Svensson B and Thor A: Implant survival following sinus membrane elevation without grafting and immediate implant installation with a one-stage technique: An up-to-40-month evaluation. Clin Oral Implants Res 28: 1354-1359, 2017.

10. Cricchio G, Sennerby L and Lundgren S: Sinus bone formation and implant survival after sinus membrane elevation and implant placement: A 1- to 6-year follow-up study. Clin Oral Implants Res 22: 1200-1212, 2011.

11. Cordaro L, Bosshardt DD, Palattella P, Rao W, Serino G and Chiapasco M: Maxillary sinus grafting with Bio-Oss or Straumann Bone Ceramic: Histomorphometric results from a randomized controlled multicenter clinical trial. Clin Oral Implants Res 19: 796-803, 2008.

12. Avera SP, Stampley WA and McAllister BS: Histologic and clinical observations of resorbable and nonresorbable barrier membranes used in maxillary sinus graft containment. Int J Oral Maxillofac Implants 12: 88-94, 1997.

13. Graziano A, Benedetti L, Massei G, Cusella de Angelis MG, Ferrarotti $\mathrm{F}$ and Aimetti M: Bone production by human maxillary sinus mucosa cells. J Cell Physiol 227: 3278-3281, 2012.

14. Gruber R, Kandler B, Fuerst G, Fischer MB and Watzek G: Porcine sinus mucosa holds cells that respond to bone morphogenetic protein (BMP)-6 and BMP-7 with increased osteogenic differentiation in vitro. Clin Oral Implants Res 15: 575-580, 2004.

15. Guo J, Weng J, Rong Q, Zhang X, Zhu S, Huang D, Li X and Chen S: Investigation of multipotent postnatal stem cells from human maxillary sinus membrane. Sci Rep 5: 11660, 2015. 
16. Srouji S, Kizhner T, Ben David D, Riminucci M, Bianco P and Livne E: The Schneiderian membrane contains osteoprogenitor cells: In vivo and in vitro study. Calcif Tissue Int 84: 138-145, 2009.

17. Kim SW, Lee IK, Yun KI, Kim CH and Park JU: Adult stem cells derived from human maxillary sinus membrane and their osteogenic differentiation. Int J Oral Maxillofac Implants 24: 991-998, 2009.

18. Berberi A, Al-Nemer F, Hamade E, Noujeim Z, Badran B and Zibara K: Mesenchymal stem cells with osteogenic potential in human maxillary sinus membrane: An in vitro study. Clin Oral Investig 21: 1599-1609, 2017.

19. Cho KS, Park HY, Roh HJ, Bravo DT, Hwang PH and Nayak JV: Human ethmoid sinus mucosa: A promising novel tissue source of mesenchymal progenitor cells. Stem Cell Res Ther 5: 15, 2014.

20. Lin GH, Lim G, Chan HL, Giannobile WV and Wang HL: Recombinant human bone morphogenetic protein 2 outcomes for maxillary sinus floor augmentation: A systematic review and meta-analysis. Clin Oral Implants Res 27: 1349-1359, 2016.

21. Yamaguchi A, Komori T and Suda T: Regulation of osteoblast differentiation mediated by bone morphogenetic proteins, hedgehogs, and Cbfa1. Endocr Rev 21: 393-411, 2000.

22. Itoh S, Itoh F, Goumans MJ and Ten Dijke P: Signaling of transforming growth factor-beta family members through Smad proteins. Eur J Biochem 267: 6954-6967, 2000.

23. Miyazono K: Positive and negative regulation of TGF-beta signaling. J Cell Sci 113: 1101-1109, 2000.

24. Lee MH, Kim YJ, Kim HJ, Park HD, Kang AR, Kyung HM, Sung JH, Wozney JM, Kim HJ and Ryoo HM: BMP-2-induced Runx 2 expression is mediated by Dlx5, and TGF-beta 1 opposes the BMP-2-induced osteoblast differentiation by suppression of Dlx5 expression. J Biol Chem 278: 34387-34394, 2003.

25. Lee MH, Kwon TG, Park HS, Wozney JM and Ryoo HM: BMP-2-induced Osterix expression is mediated by Dlx 5 but is independent of Runx2. Biochem Biophys Res Commun 309: 689-694, 2003

26. Nakashima M and Reddi AH: The application of bone morphogenetic proteins to dental tissue engineering. Nat Biotechnol 21 1025-1032, 2003

27. Bowler D and Dym H: Bone morphogenic protein: Application in implant dentistry. Dent Clin North Am 59: 493-503, 2015.

28. Srouji S, Ben-David D, Lotan R, Riminucci M, Livne E and Bianco P: The innate osteogenic potential of the maxillary sinus (Schneiderian) membrane: An ectopic tissue transplant model simulating sinus lifting. Int J Oral Maxillofac Surg 39: 793-801, 2010.

29. Sohn DS and Moon YS: Histomorphometric study of rabbit's maxillary sinus augmentation with various graft materials. Anat Cell Biol 51 (Suppl 1): S1-S12, 2018.

30. Valentin-Opran A, Wozney J, Csimma C, Lilly L and Riedel GE: Clinical evaluation of recombinant human bone morphogenetic protein-2. Clin Orthop Relat Res 110-120, 2002.

31. Haugen HJ, Lyngstadaas SP, Rossi F and Perale G: Bone grafts: Which is the ideal biomaterial? J Clin Periodontol 46 (Suppl 21): S92-S102, 2019.

32. Jung RE, Glauser R, Scharer P, Hammerle CH, Sailer HF and Weber FE: Effect of rhBMP-2 on guided bone regeneration in humans. Clin Oral Implants Res 14: 556-568, 2003.

33. Freitas RM, Spin-Neto R, Marcantonio Junior E, Pereira LA, Wikesjö UM and Susin C: Alveolar ridge and maxillary sinus augmentation using rhBMP-2: A systematic review. Clin Implant Dent Relat Res 17 (Suppl 1): e192-e201, 2015.

34. Boyne PJ, Lilly LC, Marx RE, Moy PK, Nevins M, Spagnoli DB and Triplett RG: De novo bone induction by recombinant human bone morphogenetic protein-2 (rhBMP-2) in maxillary sinus floor augmentation. J Oral Maxillofac Surg 63: 1693-1707, 2005.

35. Torrecillas-Martinez L, Monje A, Pikos MA, Ortega-Oller I, Suarez F, Galindo-Moreno P and Wang HL: Effect of rhBMP-2 upon maxillary sinus augmentation: A comprehensive review. Implant Dent 22: 232-237, 2013

36. James AW, LaChaud G, Shen J, Asatrian G, Nguyen V, Zhang X, Ting $\mathrm{K}$ and Soo $\mathrm{C}$ : A review of the clinical side effects of bone morphogenetic protein-2. Tissue Eng Part B Rev 22: 284-297, 2016

37. Lee KB, Taghavi CE, Murray SS, Song KJ, Keorochana G and Wang JC: BMP induced inflammation: A comparison of rhBMP-7 and rhBMP-2. J Orthop Res 30: 1985-1994, 2012.

38. Woo EJ: Adverse events reported after the use of recombinant human bone morphogenetic protein 2. J Oral Maxillofac Surg 70 765-767, 2012.
39. Livak KJ and Schmittgen TD: Analysis of relative gene expression data using real-time quantitative PCR and the 2(-Delta Delta C(T)) method. Methods 25: 402-408, 2001.

40. Pjetursson BE, Tan WC, Zwahlen M and Lang NP: A systematic review of the success of sinus floor elevation and survival of implants inserted in combination with sinus floor elevation. J Clin Periodontol 35 (Suppl 8): S216-S240, 2008.

41. Mohan N, Wolf J and Dym H: Maxillary sinus augmentation. Dent Clin North Am 59: 375-388, 2015.

42. Tawil G, Barbeck M, Unger R, Tawil P and Witte F: Sinus floor elevation using the lateral approach and window repositioning and a xenogeneic bone substitute as a grafting material: A histologic, histomorphometric, and radiographic analysis. Int J Oral Maxillofac Implants 33: 1089-1096, 2018.

43. Baksh D, Song L and Tuan RS: Adult mesenchymal stem cells Characterization, differentiation, and application in cell and gene therapy. J Cell Mol Med 8: 301-316, 2004.

44. Kelly MP, Vaughn OL and Anderson PA: Systematic review and meta-analysis of recombinant human bone morphogenetic protein-2 in localized alveolar ridge and maxillary sinus augmentation. J Oral Maxillofac Surg 74: 928-939, 2016.

45. Väänänen HK: Mesenchymal stem cells. Ann Med 37: 469-479, 2005.

46. Dennis JE, Carbillet JP, Caplan AI and Charbord P: The STRO-1+ marrow cell population is multipotential. Cells Tissues Organs 170: 73-82, 2002.

47. Shi S and Gronthos S: Perivascular niche of postnatal mesenchymal stem cells in human bone marrow and dental pulp. J Bone Miner Res 18: 696-704, 2003.

48. Chaudhury H, Raborn E, Goldie LC and Hirschi KK: Stem cell-derived vascular endothelial cells and their potential application in regenerative medicine. Cells Tissues Organs 195: 41-47, 2012.

49. Litvinov SV, Velders MP, Bakker HA, Fleuren GJ and Warnaar SO Ep-CAM: A human epithelial antigen is a homophilic cell-cell adhesion molecule. J Cell Biol 125: 437-446, 1994.

50. Strutz F, Okada H, Lo CW, Danoff T, Carone RL, Tomaszewski JE and Neilson EG: Identification and characterization of a fibroblast marker: FSP1. J Cell Biol 130: 393-405, 1995.

51. Draenert FG, Nonnenmacher AL, Kammerer PW, Goldschmitt J and Wagner W: BMP-2 and bFGF release and in vitro effect on human osteoblasts after adsorption to bone grafts and biomaterials. Clin Oral Implants Res 24: 750-757, 2013.

52. Kao DW, Kubota A, Nevins M and Fiorellini JP: The negative effect of combining rhBMP-2 and Bio-Oss on bone formation for maxillary sinus augmentation. Int J Periodontics Restorative Dent 32: 61-67, 2012.

53. Nguyen V, Meyers CA, Yan N, Agarwal S, Levi B and James AW: BMP-2-induced bone formation and neural inflammation. J Orthop 14: 252-256, 2017.

54. Huang RL, Yuan Y, Tu J, Zou GM and Li Q: Opposing TNF- $\alpha /$ IL-1 $\beta$ - and BMP-2-activated MAPK signaling pathways converge on Runx2 to regulate BMP-2-induced osteoblastic differentiation. Cell Death Dis 5: e1187, 2014.

55. Aggarwal S and Pittenger MF: Human mesenchymal stem cells modulate allogeneic immune cell responses. Blood 105: 1815-1822, 2005.

56. Sotiropoulou PA and Papamichail M: Immune properties of mesenchymal stem cells. Methods in molecular biology 407: 225-243, 2007.

57. Gonzalez-Rey E, Gonzalez MA, Varela N, O'Valle F, Hernandez-Cortes P, Rico L, Büscher D and Delgado M: Human adipose-derived mesenchymal stem cells reduce inflammatory and $\mathrm{T}$ cell responses and induce regulatory $\mathrm{T}$ cells in vitro in rheumatoid arthritis. Ann Rheum Dis 69: 241-248, 2010.

58. Prockop DJ and Oh JY: Mesenchymal stem/stromal cells (MSCs): Role as guardians of inflammation. Mol Ther 20: 14-20, 2012.

59. Castro-Manrreza ME: Participation of mesenchymal stem cells in the regulation of immune response and cancer development. Bol Med Hosp Infant Mex 73: 380-387, 2016

60. Zara JN, Siu RK, Zhang X, Shen J, Ngo R, Lee M, Li W, Chiang M, Chung J, Kwak J, et al: High doses of bone morphogenetic protein 2 induce structurally abnormal bone and inflammation in vivo. Tissue Eng Part A 17: 1389-1399, 2011.

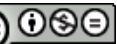

This work is licensed under a Creative Commons Attribution-NonCommercial-NoDerivatives 4.0 International (CC BY-NC-ND 4.0) License. 